Article

\title{
The Effect of Alloying Elements on the Structural Stability, and Mechanical and Electronic Properties of $\mathrm{Al}_{3}$ Sc: A First-Principles Study
}

\author{
Dong Chen ${ }^{1,2}$, Cunjuan Xia ${ }^{1}$, Xiaomin Liu ${ }^{1, *}$, Yi Wu ${ }^{2}$ and Mingliang Wang ${ }^{2, *}$ \\ 1 State Key Laboratory of Metal Matrix Composites, Shanghai Jiao Tong University, No. 800 Dongchuan Road, \\ Shanghai 200240, China; chend@sjtu.edu.cn (D.C.); xiacunjuan@sjtu.edu.cn (C.X.) \\ 2 School of Materials Science \& Engineering, Shanghai Jiao Tong University, No. 800 Dongchuan Road, \\ Shanghai 200240, China; eagle51@sjtu.edu.cn \\ * Correspondence: 15714312116@163.com (X.L.); mingliang_wang@sjtu.edu.cn (M.W.)
}

Received: 15 April 2019; Accepted: 8 May 2019; Published: 10 May 2019

\begin{abstract}
The first-principles methods, based on the density function theory, are performed to calculate the properties of pure and doped $\mathrm{Al}_{3} \mathrm{Sc}$. The structural stability, and mechanical and electronic properties of $\mathrm{L}_{2}-\mathrm{Al}_{3} \mathrm{Sc}_{1-x} \mathrm{M}_{x}(\mathrm{M}=\mathrm{Zr}, \mathrm{Ti}, \mathrm{Y}$, and $\mathrm{Li})$ have been investigated. A negative formation enthalpy for $\mathrm{L}_{2}-\mathrm{Al}_{3} \mathrm{Sc}_{1-x} \mathrm{M}_{x}$ indicated that all doped structures were stable, and $\mathrm{Al}_{24} \mathrm{Sc}_{6} \mathrm{Zr}_{2}$ was found to be the most stable. The elastic constants, elastic moduli and Debye temperatures of $\mathrm{Al}_{3} \mathrm{Sc}$, with different doping elements and different doping concentrations, were calculated to explore the influences of doping on the mechanical properties and Debye temperatures of $\mathrm{Al}_{3} \mathrm{Sc}$. Furthermore, the calculated results suggested that both $\mathrm{Al}_{24} \mathrm{Sc}_{6} \mathrm{Zr}_{2}$ and $\mathrm{Al}_{24} \mathrm{Sc}_{6} \mathrm{Ti}_{2}$ could optimize the mechanical properties. Finally, the electronic properties based on the analyses of densities of states and electron density distributions, have been performed, to explain the underlying mechanisms for the structural and mechanical properties of the $\mathrm{L}_{2}-\mathrm{Al}_{3} \mathrm{Sc}_{1-x} \mathrm{M}_{x}$ structures.
\end{abstract}

Keywords: ab-initio calculations; structural stability; elastic properties; electronic properties

\section{Introduction}

In the past decades, Al-Sc alloys have attracted great attention, due to higher strength and stiffness, compared with pure $\mathrm{Al}[1,2]$. The addition of Sc can greatly improve the mechanical properties of $\mathrm{Al}$ alloy, since a large number of nanoparticles $\left(\mathrm{Al}_{3} \mathrm{Sc}\right)$ are formed in the aging process [3-5], and $\mathrm{Al}_{3} \mathrm{Sc}$ with a cubic $\mathrm{L}_{2}$ structure has a small lattice mismatch with $\alpha$-Al. However, the industrial application of $\mathrm{Al}_{3} \mathrm{Sc}$ has been limited because of the high cost of Sc, and the low solubility of Sc in $\mathrm{Al}$. As a result, it is necessary to find an element to replace Sc, which can improve the mechanical properties of the alloy and reduce its cost.

In recent years, researcher has shown that doping has a certain impact on the structural characteristics and mechanical properties of alloys, through experimental investigations [6-9] and theoretical calculations [10-12]. The behaviors and properties of the alloying elements in $\mathrm{Al}_{3} \mathrm{Sc}$, have been studied by experiments. For example, Fuller et al. studied the replacement of Sc by $\mathrm{Zr}$ in Al-Sc alloys, and found that the coarsening resistance was increased at higher temperatures [13]. Dalen et al. studied the effects of Ti additions on the structural and creep properties of Al-Sc alloys [14]. Seidman et al. indicated that the addition of $\mathrm{Li}$ has resulted in an increased driving force for precipitate nucleation [15]. Harada et al. compared the thermal expansion and creep properties of $\mathrm{Al}_{3} \mathrm{Sc}$ and $\mathrm{Al}_{3}(\mathrm{Sc}, \mathrm{Y})[16,17]$. Up to now, the microstructure, compression, fracture behavior, elastic and optical properties of $\mathrm{Al}_{3} \mathrm{Sc}$ have been widely researched $[18,19]$ by the density functional theory(DFT) method. Furthermore, the structural, electronic, mechanical, and thermodynamic properties of $\mathrm{Al}_{3} \mathrm{Sc}$, under 
different pressures and temperatures, have been calculated [20-22]. Moreover, the effect of transition metals on the structural stability of $\mathrm{Al}_{3} \mathrm{Sc}_{1-\mathrm{x}} \mathrm{M}_{\mathrm{x}}$ was studied by the special quasi random structures method [23]. In addition, the properties of $\mathrm{Al}_{3} \mathrm{Sc}_{1-x} \mathrm{M}_{x}(\mathrm{M}=\mathrm{Zr}$, Ti) with different concentrates, were performed [24,25]. Nevertheless, the influences of the doping elements on the mechanical and electronic properties of the Al-Sc-M system have required further investigations.

In this work, we calculated the structural stability and mechanical properties of the $\mathrm{L1}_{2}-\mathrm{Al}_{3} \mathrm{Sc}_{1-x} \mathrm{M}_{x}$ $(\mathrm{M}=\mathrm{Zr}, \mathrm{Ti}, \mathrm{Y}$, and $\mathrm{Li})$ structures with concentrations of 3.125 at.\% and 6.25 at.\%. Second, the mechanical properties and electronic properties of the $\mathrm{L}_{2}-\mathrm{Al}_{3} \mathrm{Sc}_{1-x} \mathrm{TM}_{x}$ structures have been intensively discussed in relation to their electronic properties. This investigation could provide theoretical guidance to the application of Al-Sc-based alloys.

\section{Materials and Methods}

All calculations were performed on the basis of the density functional theory (DFT) with the Vienna Ab Initio Simulation Package (VASP) [26]. The pseudopotential in the reciprocal space was described by the projector-augmented wave (PAW) method [27]. The generalized gradient approximation (GGA), with the Perdew-Burke-Ernzerhof (PBE) [28] function was applied to describe the exchange-correlation potential. Both the $\mathrm{k}$-space integral and plane-wave basis were chosen to ensure that the total energy was converged. The convergence criterion for the self-consistent field energy was set to be $5 \times 10^{-6} \mathrm{eV} /$ atom. For the plane wave expansion, a kinetic cutoff energy of $500 \mathrm{eV}$ was considered to be sufficient. The geometry optimization was terminated when the Hellman-Feynman force on each atom was smaller than the $0.003 \mathrm{eV} / \mathrm{nm}$. The integral in the Brillouin zone was sampled by the Monkhorst-Pack method [29], with the k-point mesh of $21 \times 21 \times 21$ for $\mathrm{Al}_{3} \mathrm{Sc}$ and $11 \times 11 \times$ 11 for the $2 \times 2 \times 2$ supercells. All calculations were carried out with the potentials for $\operatorname{Al}\left(3 s^{2} 3 p^{1}\right)$, $\operatorname{Li}\left(1 s^{2} 2 s^{1}\right), \operatorname{Sc}\left(3 s^{2} 3 p^{6} 3 d^{1} 4 s^{2}\right), \operatorname{Ti}\left(3 s^{2} 3 p^{6} 3 d^{2} 4 s^{2}\right), \operatorname{Zr}\left(4 s^{2} 4 p^{6} 4 d^{2} 5 s^{2}\right)$, and $\mathrm{Y}\left(4 s^{2} 4 p^{6} 4 d^{1} 5 s^{2}\right)$, as the valence electrons. Overall, all calculations were operated in $0 \mathrm{~K}$, with the equivalent hydrostatic pressure.

\section{Results}

\subsection{Structural Stability}

The $\mathrm{Al}_{3} \mathrm{Sc}$ phase had a cubic structure (Space Group: Pm3m (No. 221)), which contained $3 \mathrm{Al}$ atoms and $1 \mathrm{Sc}$ atom, in a unit cell. Based on the $\mathrm{Al}_{3} \mathrm{Sc}$ phase, a $2 \times 2 \times 2$ supercell (Figure 1a) was constructed to investigate the effects of the doped element $(\mathrm{M}=\mathrm{Zr}, \mathrm{Ti}, \mathrm{Y}$, and $\mathrm{Li})$. In addition, the effects of the doping concentrations (at.\%) were also considered, which included $3.125 \%$ (Figure 1b) and $6.25 \%$ (Figure 1c). The structures of the surpercells used in this work are shown in Figure 1, and the optimized structural parameters are listed in Table 1.

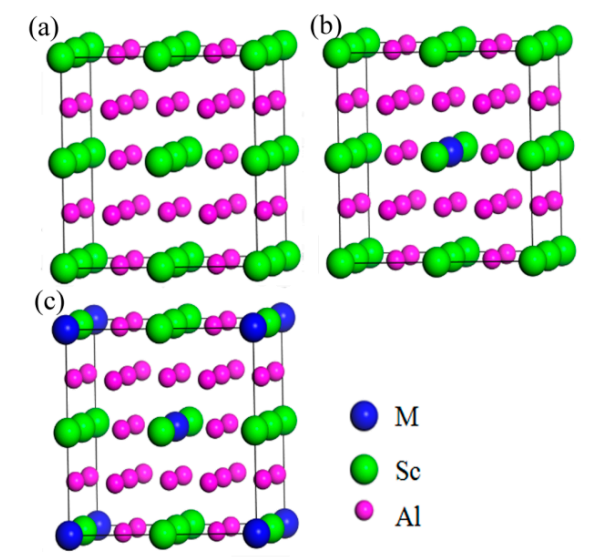

Figure 1. Structures of $\mathrm{Al}_{3} \mathrm{Sc}(\mathbf{a}) 2 \times 2 \times 2$ surpercell; doped with the alloying element $(\mathrm{M}=\mathrm{Sc}, \mathrm{Zr}, \mathrm{Ti}, \mathrm{Y}$, $\mathrm{Li}$ ) at different doping concentrations, (b) $3.125 \%$, and (c) $6.25 \%$. Blue, green, and pink balls represent $(\mathrm{M}=\mathrm{Zr} / \mathrm{Ti} / \mathrm{Y} / \mathrm{Li})$, Sc, and $\mathrm{Al}$ atoms, accordingly. 
Table 1. The crystal parameters $(\AA)$, density $\left(\rho / \mathrm{g} \cdot \mathrm{cm}^{-3}\right)$, and heat of formation $\left(\Delta H_{f} / \mathrm{eV} \cdot \mathrm{atom}^{-1}\right)$ of $\mathrm{L}_{2}-\mathrm{Al}_{3} \mathrm{Sc}_{1-x} \mathrm{M}_{x}$ at the ground state.

\begin{tabular}{cccc}
\hline Structures & $a / \AA$ & $\rho / \mathbf{g} \cdot \mathbf{c m}^{-\mathbf{3}}$ & $\boldsymbol{\Delta} \boldsymbol{H}_{f} / \mathbf{e V} \cdot \mathbf{a t o m}^{\mathbf{1}}$ \\
\hline $\mathrm{Al}_{3} \mathrm{Sc}$ & 4.107 & 3.108 & -0.443 \\
$\mathrm{Al}_{24} \mathrm{Sc}_{7} \mathrm{Zr}$ & 8.210 & 3.160 & -0.449 \\
$\mathrm{Al}_{24} \mathrm{Sc}_{6} \mathrm{Zr}_{2}$ & 8.211 & 3.298 & -0.456 \\
$\mathrm{Al}_{24} \mathrm{Sc}_{7} \mathrm{Ti}$ & 8.180 & 3.064 & -0.435 \\
$\mathrm{Al}_{24} \mathrm{Sc}_{6} \mathrm{Ti}_{2}$ & 8.144 & 3.155 & -0.427 \\
$\mathrm{Al}_{24} \mathrm{Sc}_{7} \mathrm{Y}$ & 8.252 & 3.106 & -0.438 \\
$\mathrm{Al}_{24} \mathrm{Sc}_{6} \mathrm{Y}_{2}$ & 8.291 & 3.19 & -0.432 \\
$\mathrm{Al}_{24} \mathrm{Sc}_{7} \mathrm{Li}$ & 8.201 & 2.917 & -0.396 \\
$\mathrm{Al}_{24} \mathrm{Sc}_{6} \mathrm{Li}_{2}$ & 8.193 & 2.812 & -0.35 \\
\hline
\end{tabular}

It is well-known that a lower formation energy implies a more stable structure. In order to study the influence of the doped elements on the structural stability, the enthalpies of formation $\left(\Delta H_{f}\right)$ of the $\mathrm{Al}_{3} \mathrm{Sc}$ structure, before and after doping, were calculated with the following formula:

$$
\Delta H_{f}=\frac{1}{n}\left(E_{t o t a l}-N_{A l} E_{A l}-N_{S c} E_{S c}-N_{M} E_{M}\right)
$$

where $E_{\text {total }}$ is the total energy of the doped structure; $\mathrm{n}$ stands for the total number of atoms in the Al-Sc-M system; $E_{i}$ and $N_{i}$ are the energies per atom of species $i$, and the corresponding number of atoms in the doped structure. The energies per atom of $\mathrm{Al}, \mathrm{Sc}$, and $\mathrm{M}(\mathrm{M}=\mathrm{Zr} / \mathrm{Ti} / \mathrm{Y} / \mathrm{Li})$ were calculated from bulk $\mathrm{Al}$ with an FCC structure, a bulk Sc and $\mathrm{M}(\mathrm{M}=\mathrm{Zr} / \mathrm{Ti} / \mathrm{Y})$ with an $\mathrm{HCP}$ structure, and a bulk $\mathrm{M}(\mathrm{M}=\mathrm{Li})$ with a BCC structure.

The calculation results of $\Delta \mathrm{H}_{f}$ are listed in Table 1. The negative $\Delta \mathrm{H}_{f}$ indicates that the doped structure could stably form at $0 \mathrm{~K}$; all structures were stable. However, the $\Delta \mathrm{H}_{f}$ values of the doped structures were greater than that of pure $\mathrm{Al}_{3} \mathrm{Sc}$, except for the $\mathrm{Al}-\mathrm{Sc}-\mathrm{Zr}$ system. This meant that $\mathrm{Zr}$ doping could improve stability, while the Ti/Y/Li dopings might reduce the structural stability. This was consistent with results from previous studies [23,30]. In addition, it was found that the stability of $\mathrm{Al}_{24} \mathrm{Sc}_{6} \mathrm{Zr}_{2}$ was higher in comparison to $\mathrm{Al}_{24} \mathrm{Sc}_{7} \mathrm{Zr}$. Except for the $\mathrm{Zr}$ addition, the higher concentration dopings should have caused a lower stability of the structure.

\subsection{Elastic Properties}

The elastic properties could provide necessary information on the resistance of the material to extrinsically applied stress. For the cubic crystals, there were three independent elastic constants (i.e., $\mathrm{C}_{11}, \mathrm{C}_{12}$, and $\mathrm{C}_{44}$ ). The calculated results of the elastic constants are listed in Table 2.

Table 2. Calculated elastic constants $\mathrm{Cij}$ for $\mathrm{L}_{2}-\mathrm{Al}_{3} \mathrm{Sc}_{1-x} \mathrm{M}_{x}$ at the ground state.

\begin{tabular}{cccccc}
\hline Structures & $\mathbf{C}_{\mathbf{1 1}}(\mathbf{G P a})$ & $\mathbf{C}_{\mathbf{1 2}}$ (GPa) & $\mathbf{C}_{\mathbf{4 4}}$ (GPa) & $\mathbf{C}_{\mathbf{1 1}}-\mathrm{C}_{\mathbf{1 2}}$ (GPa) & $\mathbf{C}_{\mathbf{1 2}}-\mathbf{C}_{\mathbf{4 4}}$ (GPa) \\
\hline $\mathrm{Al}_{3} \mathrm{Sc}$ & 183.99 & 37.81 & 71.94 & 146.18 & -34.13 \\
Exp. [31] & 183 & 46 & 68 & 137 & -22 \\
$\mathrm{DFT}[15]$ & 180.67 & 40.62 & 72 & 140.05 & -31.38 \\
$\mathrm{Al}_{24} \mathrm{Sc}_{7} \mathrm{Zr}$ & 181.2 & 40.89 & 69.44 & 140.31 & -28.55 \\
$\mathrm{Al}_{24} \mathrm{Sc}_{6} \mathrm{Zr}_{2}$ & 183.93 & 42.9 & 69.07 & 141.03 & -26.17 \\
$\mathrm{Al}_{24} \mathrm{Sc}_{7} \mathrm{Ti}$ & 181.66 & 40.88 & 69.58 & 140.79 & -28.7 \\
$\mathrm{Al}_{24} \mathrm{Sc}_{6} \mathrm{Ti}_{2}$ & 186.41 & 43.325 & 69.26 & 143.09 & -25.94 \\
$\mathrm{Al}_{24} \mathrm{Sc}_{7} \mathrm{Y}$ & 175.77 & 38.08 & 68.59 & 137.69 & -30.51 \\
$\mathrm{Al}_{24} \mathrm{Sc}_{6} \mathrm{Y}_{2}$ & 171.96 & 38.55 & 67.93 & 133.41 & -29.38 \\
$\mathrm{Al}_{24} \mathrm{Sc}_{7} \mathrm{Li}$ & 167.18 & 38.05 & 69.69 & 129.37 & -31.64 \\
$\mathrm{Al}_{24} \mathrm{Sc}_{6} \mathrm{Li}_{2}$ & 163.42 & 39.34 & 68.41 & 124.08 & -29.07 \\
\hline
\end{tabular}

Note: Exp. represents the reported "experimental results". 
Notably, the results of $\mathrm{Al}_{3} \mathrm{Sc}$ were close to the published DFT calculations [15] and experimental measurements [31], implying the reliability of the calculation results. The criterions for the mechanical stability of the cubic crystal [32] were estimated using Equation (2):

$$
\mathrm{C}_{11}-\mathrm{C}_{12}>0, \mathrm{C}_{11}>0, \mathrm{C}_{44}>0, \mathrm{C}_{11}+2 \mathrm{C}_{12}>0
$$

The calculated results showed that the elastic constants of all structures could satisfy the above stability conditions, indicating that all structures had mechanical stability.

The calculated elastic constants as a function of doping concentration for $\mathrm{Al}_{3} \mathrm{Sc}$ are exhibited in Figure 2. The $\mathrm{C}_{11}$ values of $\mathrm{Al}_{3} \mathrm{Sc}$, before and after doping, were larger than the other elastic constants (Figure 2a), suggesting that the axes compression resistances were stronger. The $C_{11}$ values in the $\mathrm{Al}_{24} \mathrm{Sc}_{7} \mathrm{M}$ system were obviously decreased, which proved that the axes pressure resistances were reduced. However, $\mathrm{Al}_{24} \mathrm{Sc}_{6} \mathrm{M}_{2}$ have found to be quite complex. For example, $\mathrm{Al}_{24} \mathrm{Sc}_{6} \mathrm{Y}_{2}$ and $\mathrm{Al}_{24} \mathrm{Sc}_{6} \mathrm{Li}_{2}$ have smaller $\mathrm{C}_{11}$ values, $\mathrm{Al}_{24} \mathrm{Sc}_{6} \mathrm{Zr}_{2}$ had a similar $\mathrm{C}_{11}$ value, and $\mathrm{Al}_{24} \mathrm{Sc}_{6} \mathrm{Ti}_{2}$ possessed a larger $\mathrm{C}_{11}$ value. On the other hand, both $\mathrm{Al}_{24} \mathrm{Sc}_{7} \mathrm{M}$ and $\mathrm{Al}_{24} \mathrm{Sc}_{6} \mathrm{M}_{2}$ exhibited higher $\mathrm{C}_{12}$ values (Figure $2 \mathrm{~b}$ ), suggesting that the Poisson effect was enhanced [25]. Additionally, the Al-Sc-M systems had shown a slightly reduced tendency for $\mathrm{C}_{44}$ (Figure 2c), especially for the $\mathrm{Al}_{24} \mathrm{Sc}_{6} \mathrm{M}_{2}$, indicating that the resistance to shear deformation was gently diminished.
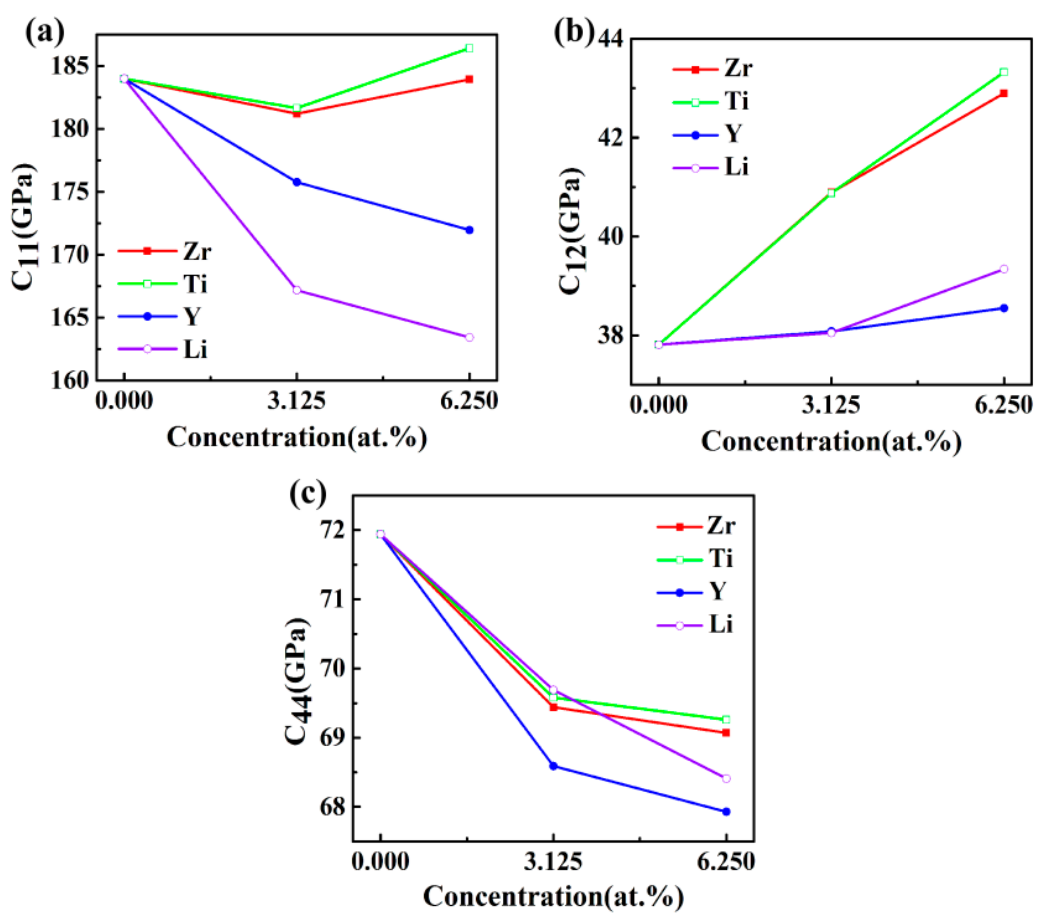

Figure 2. The elastic constants $\mathrm{C}_{\mathrm{ij}}(\mathrm{GPa})$ of $\mathrm{L}_{2}-\mathrm{Al}_{3} \mathrm{Sc}$ doped with the element $\mathrm{M}(\mathrm{M}=\mathrm{Zr}, \mathrm{Ti}, \mathrm{Y}$, and Li) on the dependence of doping concentration: (a) $C_{11}$, (b) $C_{12}$, and (c) $C_{44}$.

The polycrystalline elastic moduli are the important performance parameters of engineering materials, such as bulk modulus $(B)$, shear modulus $(G)$, Young's modulus $(E)$, and Poisson's ratio $(v)$. The bulk modulus and shear modulus were determined using the Voigt-Reuss-Hill method [33]. For the cubic structure, the bulk modulus $(B)$ and shear modulus $(G)$ were calculated from Equations (3) and (4), respectively:

$$
\begin{aligned}
& B=B_{V}=B_{R}=\left(C_{11}+2 C_{12}\right) / 3 \\
& G_{V}=\left(C_{11}-C_{12}+3 C_{44}\right) / 5 \\
& G_{R}=5\left(C_{11}-C_{12}\right) C_{44} /\left[3\left(C_{11}-C_{12}\right)+4 C_{44}\right] \\
& G=\left(G_{V}+G_{R}\right) / 2
\end{aligned}
$$


Young's modulus $(E)$ and Poisson's ratio $(v)$ were determined by $B$ and $G$, and their expressions are shown in Equations (5) and (6) [34]:

$$
\begin{gathered}
E=9 G B /(3 B+G) \\
v=(3 B-2 G) / 2(3 B+G)
\end{gathered}
$$

The results of the elastic moduli are listed in Table 3. It is well-known that $B$ is a measure of the degree to which a material deforms under hydrostatic pressure [35]. $G$ indicates the material's resistance to shear strain [35]. $E$ is a representation of the stiffness of the material [36].

Table 3. Elastic moduli $B, G, E, v, B / G, H, A$ and $\Theta_{D}$ for $\mathrm{L}_{2}-\mathrm{Al}_{3} \mathrm{Sc}_{1-x} \mathrm{M}_{x}$, at the ground state.

\begin{tabular}{ccccccccc}
\hline Structures & $\boldsymbol{B}(\mathrm{GPa})$ & $\boldsymbol{G}(\mathbf{G P a})$ & $\boldsymbol{E}(\mathrm{GPa})$ & $\boldsymbol{v}$ & $\boldsymbol{B} / \boldsymbol{G}$ & $\boldsymbol{A}$ & $\boldsymbol{H}(\mathrm{GPa})$ & $\boldsymbol{\Theta}_{\boldsymbol{D}}(\mathbf{K})$ \\
\hline $\mathrm{Al}_{3} \mathrm{Sc}$ & 86.53 & 72.4 & 169.84 & 0.173 & 1.195 & 0.98 & 15.78 & 607 \\
Exp. [31] & 91.7 & 71.7 & 170.63 & 0.201 & 1.28 & 0.99 & & \\
DFT [15] & 87.3 & 71.2 & 167.94 & 0.179 & 1.23 & 1.03 & & \\
$\mathrm{Al}_{24} \mathrm{Sc}_{7} \mathrm{Zr}$ & 87.66 & 69.73 & 165.34 & 0.186 & 1.257 & 0.99 & 14.59 & 596 \\
$\mathrm{Al}_{24} \mathrm{Sc}_{6} \mathrm{Zr}_{2}$ & 89.91 & 69.64 & 166.06 & 0.192 & 1.291 & 0.98 & 14.3 & 590 \\
$\mathrm{Al}_{24} \mathrm{Sc}_{7} \mathrm{Ti}$ & 87.81 & 69.91 & 165.74 & 0.185 & 1.256 & 0.98 & 14.68 & 610 \\
$\mathrm{Al}_{24} \mathrm{Sc}_{6} \mathrm{Ti}_{2}$ & 91.02 & 70.16 & 167.48 & 0.193 & 1.297 & 0.97 & 14.37 & 608 \\
$\mathrm{Al}_{24} \mathrm{Sc}_{7} \mathrm{Y}$ & 83.98 & 68.64 & 161.93 & 0.179 & 1.223 & 0.99 & 14.7 & 594 \\
$\mathrm{Al}_{24} \mathrm{Sc}_{6} \mathrm{Y}_{2}$ & 83.02 & 67.44 & 159.21 & 0.18 & 1.23 & 1.02 & 14.39 & 580 \\
$\mathrm{Al}_{24} \mathrm{Sc}_{7} \mathrm{Li}$ & 81.09 & 67.64 & 158.77 & 0.174 & 1.199 & 1.07 & 14.61 & 611 \\
$\mathrm{Al}_{24} \mathrm{Sc}_{6} \mathrm{Li}_{2}$ & 80.97 & 65.78 & 155.43 & 0.18 & 1.231 & 1.10 & 14.05 & 619 \\
\hline
\end{tabular}

Notes: $A$ is defined for elastic anisotropy, and $\Theta_{D}$ is for Debye temperature.

The influences of doped elements at different concentrations on the elastic modulus of $\mathrm{Al}_{3} \mathrm{Sc}$ are displayed in Figure 3a-c. The values of $B$ doped with $\mathrm{Zr}$ and Ti increased with a growing doping concentration, while the values of $B$ doped with $\mathrm{Y}$ and $\mathrm{Li}$ decreased with an increasing doping concentration. When the doping concentration was constant, Ti doped Al-Sc-M compounds had the maximum $B$ values, implying that the addition of Ti into $\mathrm{Al}_{3} \mathrm{Sc}$ resulted in minimal deformation, under certain external pressure.
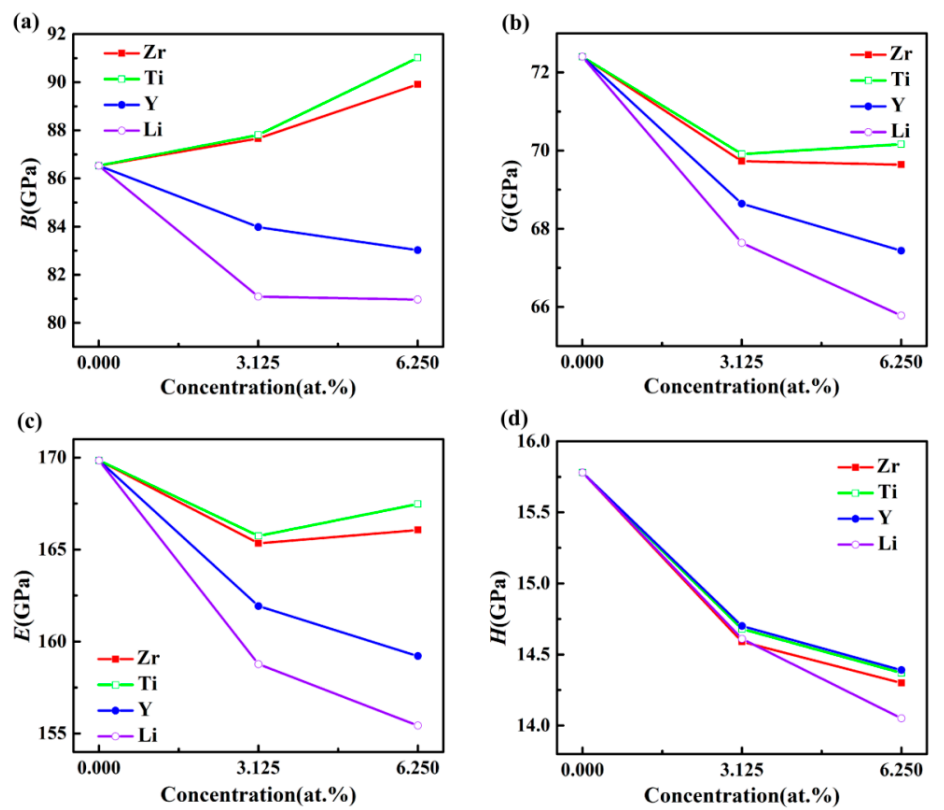

Figure 3. The elastic moduli $B(\mathbf{a}), G(\mathbf{b}), E(\mathbf{c})$, and hardness $H(\mathrm{GPa}),(\mathbf{d})$ of $\mathrm{L}_{2}-\mathrm{Al}_{3} \mathrm{Sc}$ doped with element $\mathrm{M}(\mathrm{M}=\mathrm{Zr}, \mathrm{Ti}, \mathrm{Y}$, and $\mathrm{Li})$, as a function of the doping concentration. 
Furthermore, the doped Al-Sc-M compounds displayed lower $G$ and $E$, meaning that the shear strain resistance and stiffness were reduced. In addition, the $E$ values of $\mathrm{Al}_{3} \mathrm{Sc}$ doped with $\mathrm{Zr}$ and Ti were increased, when the doping concentrations increased from $3.125 \%$ to $6.25 \%$, indicating that the higher concentration doping showed a better performance for the Al-Sc-M ( $\mathrm{M}=\mathrm{Zr} / \mathrm{Ti})$.

The investigation of the stiffness could be completed by providing the microhardness parameter $(H)$, given by the following relation [37]:

$$
H=\frac{(1-2 v)}{6(1+v)} E
$$

Figure $3 \mathrm{~d}$ exhibits the $H$ values of $\mathrm{Al}_{3} \mathrm{Sc}$ with different doping elements and concentrations. It is clearly observed that the $H$ values of the doped $\mathrm{Al}_{3} \mathrm{Sc}$ decreased with an increasing concentration. For example, $\mathrm{Al}_{24} \mathrm{Sc}_{6} \mathrm{Ti}_{2}$ presented the maximum $H$ value. Although the $H$ values of the doped $\mathrm{Al}_{3} \mathrm{Sc}$ were decreased, the reduced magnitude was small, compared with that of $\mathrm{Al}_{3} \mathrm{Sc}$. Considering the cost of Sc, the doped $\mathrm{Al}_{3} \mathrm{Sc}$ was more valuable for industrial application.

The $B / G$ ratio was used to distinguish the ductility and brittleness of compounds [38]. The greater value of $B / G$ corresponded to a better ductility in the material. The results shown in Figure 4a indicate that the $\mathrm{L1}_{2}-\mathrm{Al}_{3} \mathrm{Sc}$ structure displayed a higher ductility, after doping. This conclusion could be proved by the Cauchy pressure $\left(C_{12}-C_{44}\right)$ [39]. Furthermore, the $B / G$ values for the doped $\mathrm{Al}_{3} \mathrm{Sc}$ increased with the elevated doping concentration, which demonstrated that a higher doping concentration enhances the ductility of $\mathrm{Al}_{3} \mathrm{Sc}$. In addition, Poisson's ratio $(v)$ reflected the transverse deformation for the material [40]. It could be clearly observed that the changing trends of $v$ with doping elements and concentrations were similar to that of $B / G$ (Figure 4). It is common knowledge that a material exhibits better ductility, when the Poisson's ratio is large. The calculated results demonstrated that a better ductility of $\mathrm{Al}_{3} \mathrm{Sc}$ doped with $\mathrm{Zr} / \mathrm{Ti}$ was exhibited, compared to $\mathrm{Y} / \mathrm{Li}$.

(a)

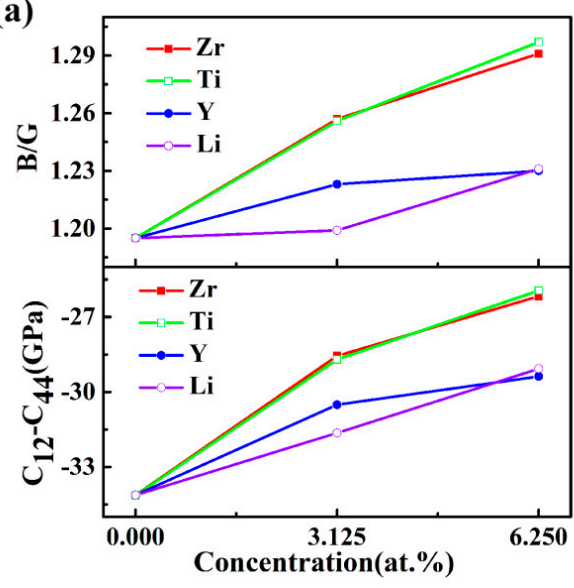

(b)

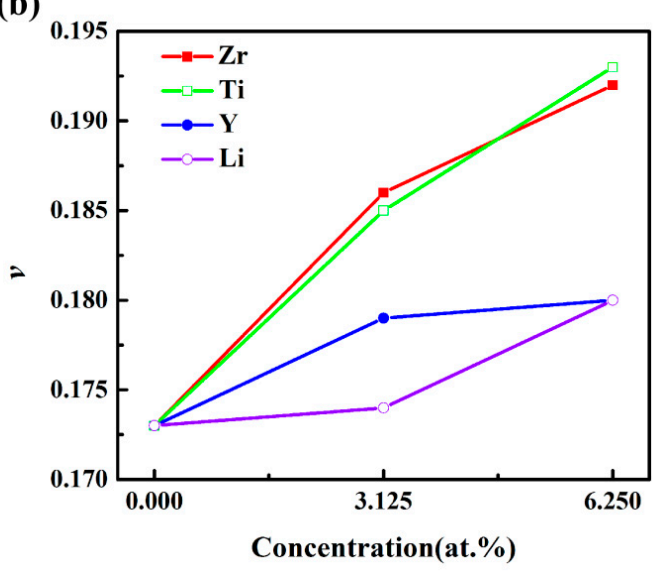

Figure 4. (a) $B / G$ and $\left(\mathrm{C}_{12}-\mathrm{C}_{44}\right)$ and (b) $v$ of $\mathrm{L1}_{2}-\mathrm{Al}_{3} \mathrm{Sc}$ doped with element $\mathrm{M}(\mathrm{M}=\mathrm{Zr}, \mathrm{Ti}, \mathrm{Y}$, and $\mathrm{Li})$ as a function of the doping concentration.

The elastic anisotropy has an important implication in engineering science, since it is highly correlated with the possibility to induce micro cracks in materials [41]. The expression of elastic anisotropy $(A)$ is shown below:

$$
A=2 C_{44} /\left(C_{11}-C_{12}\right)
$$

It is noted that the material is isotropic when $A$ is equal to 1 . The degree to which the value of $A$ deviates from 1 represents the strength of the anisotropy of the material. The $A$ values of Al-Sc-M $(\mathrm{M}=$ $\mathrm{Zr} / \mathrm{Ti} / \mathrm{Y} / \mathrm{Li}$ ) were calculated, and the results are listed in Table 3. The results showed that $\mathrm{Al}_{3} \mathrm{Sc}$ had exhibited anisotropic behavior, before and after doping. Moreover, the $A$ values for the doped $\mathrm{Al}_{3} \mathrm{Sc}$ were more deviated from 1 , when the doping concentrations varied from $3.125 \%$ to $6.25 \%$. It is worth 
noting that the deviation degree of Al-Sc-Li system was the largest. For example, $\mathrm{Al}_{24} \mathrm{Sc}_{6} \mathrm{Li}_{2}$ possessed the strongest anisotropy.

\subsection{Debye Temperature}

Debye temperature $\left(\Theta_{D}\right)$ is a fundamental parameter for the material's thermodynamic properties. It is correlated with many physical properties (i.e., specific heat, elastic constant, and melting temperature). The $\Theta_{D}$ value of a solid can usually be calculated from the sound velocity. $\Theta_{D}$ is related to the modulus of elasticity in Anderson's model [42]. Then, $\Theta_{D}$ is defined as [43]:

$$
\begin{gathered}
\Theta_{D}=\frac{h}{k}\left[\frac{3 n}{4 \pi}\left(\frac{N_{A} \rho}{M}\right)\right]^{1 / 3} v_{m} \\
v_{m}=\left[\frac{1}{3}\left(\frac{2}{v_{t}^{3}}+\frac{1}{v_{l}^{3}}\right)\right]^{-1 / 3} \\
v_{t}=\sqrt{\frac{G}{\rho}} \\
v_{l}=\sqrt{\frac{3 B+4 G}{3 \rho}}
\end{gathered}
$$

where $h, k, N_{A}, n, \rho, M, v_{m}, v_{t}$, and $v_{l}$ denote Planck's, Boltzmann's and Avogadro's constants, total number of atoms, density, molecular weight, average sound velocity, transverse sound velocity, and longitudinal sound velocity, respectively.

In the Debye theory, $\Theta_{D}$ is the temperature of a crystal's highest normal mode of vibration. That is, the highest temperature can be achieved due to a single normal vibration. It is well-known that a higher $\Theta_{D}$ corresponds to a better thermal conductivity of a material. Figure 5 describes $\Theta_{D}$ of $\mathrm{Al}_{3} \mathrm{Sc}$, at different doping elements and concentrations. The $\Theta_{D}$ values of the Al-Sc-Li structure increased with an increasing concentration. On the contrary, the $\Theta_{D}$ values of $\mathrm{Al}-\mathrm{Sc}-\mathrm{M}(\mathrm{M}=\mathrm{Zr} / \mathrm{Y})$ decrease with the increasing concentration. For the Al-Sc-Ti structure, the $\Theta_{D}$ values were a little higher than $\mathrm{Al}_{3}$ Sc. However, the $\Theta_{D}$ had decreased slightly, when the concentration increased from $3.125 \%$ to $6.25 \%$. The higher $\Theta_{D}$ values of the Al-Sc-Li structure indicated that their thermal conductivities were better, compared to other structures.

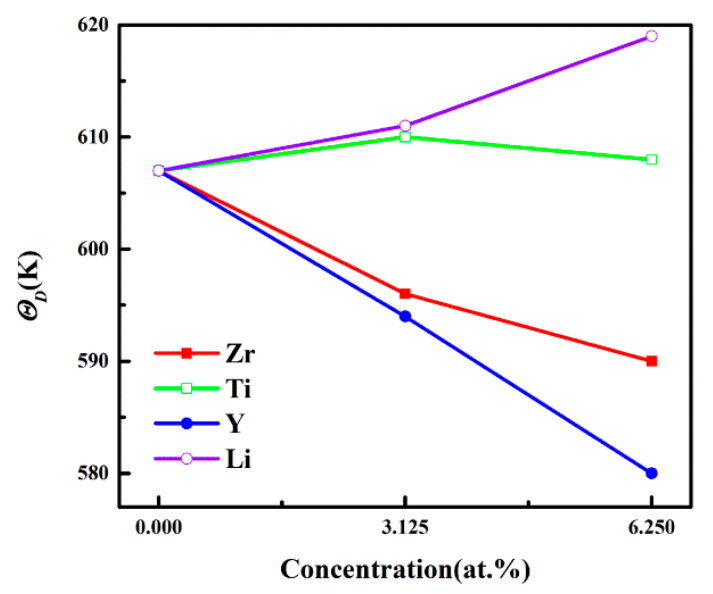

Figure 5. The $\Theta_{D}$ values of $\mathrm{L1}_{2}-\mathrm{Al}_{3} \mathrm{Sc}$ doped with element $\mathrm{M}(\mathrm{M}=\mathrm{Zr}, \mathrm{Ti}, \mathrm{Y}$, and $\mathrm{Li})$ as a function of the doping concentration.

Based on the above calculation results, it was noticeable that the species and concentrations of the doped elements had intensive impacts on the mechanical properties of $\mathrm{Al}_{3} \mathrm{Sc}$. In order to obtain high 
performance compounds, it was important to select appropriate doped element and concentration. The mechanical properties of $\mathrm{Al}_{3} \mathrm{Sc}$ before and after doping were intensively compared. It was demonstrated that doping Ti/Zr could better optimize the performances of the $\mathrm{Al}_{3} \mathrm{Sc}$ structure. This conclusion was consistent with previous reports $[14,17,23]$. Furthermore, the mechanical properties of Al-Sc-Ti were slightly better than that of Al-Sc-Zr. This discrepancy with the result, measured through experiments, might have arisen from a different temperature. It is worth noting that the experimental measurement was generally operated at $573 \mathrm{~K}$, whereas, this work was completed at $0 \mathrm{~K}$. To be more important, the structure with a higher doping concentration $(6.25 \%)$ had a higher performance over the lower doping concentration (3.125\%).

\subsection{Electronic Properties}

To gain a better understanding of the doping effects at the electronic level, the total densities of states (TDOS) and partial densities of states (PDOS) were calculated in this work. The calculated TDOS are shown in Figure 6. The Fermi energy level $\left(E_{f}\right)$ represented by a dotted line was set to zero. It could be clearly seen that the TDOS of the structure was not zero at the Fermi level, indicating that the structures had good metallic properties [2]. Meanwhile, the TDOS of $\mathrm{Al}_{24} \mathrm{Sc}_{6} \mathrm{M}_{2}(\mathrm{M}=\mathrm{Zr} / \mathrm{Ti} / \mathrm{Y} / \mathrm{Li})$ were expensed in the energy scales.

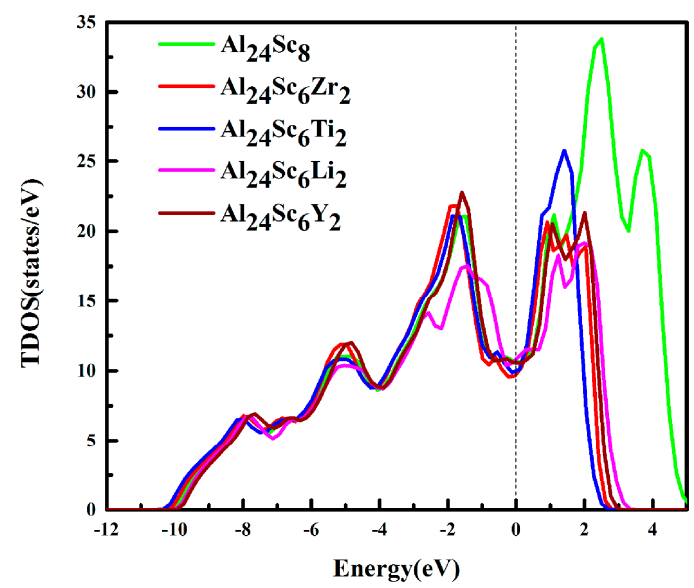

Figure 6. Total density of states (TDOSs) of the $\mathrm{Al}_{3} \mathrm{Sc}$ and $\mathrm{Al}_{24} \mathrm{Sc}_{6} \mathrm{M}_{2}(\mathrm{M}=\mathrm{Sc}, \mathrm{Zr}, \mathrm{Ti}$, $\mathrm{Li}$ and $\mathrm{Y}$ ) alloys.

The structures of $\mathrm{Al}_{3} \mathrm{Sc}$, before and after doping, had a very wide pseudogap around $E_{f}$, implying that Al-Sc-M intermetallic compounds had strong covalent bonds, indicating that it had a good stability [44]. Moreover, the widths of the pseudogap for $\mathrm{Al}_{3} \mathrm{Sc}$ and $\mathrm{Al}-\mathrm{Sc}-\mathrm{M}(\mathrm{M}=\mathrm{Zr}, \mathrm{Ti}, \mathrm{Y}$, and $\mathrm{Li}$ ) structures were $2.65 \mathrm{eV}, 2.74 \mathrm{eV}, 2.53 \mathrm{eV}, 2.59 \mathrm{eV}$, and $2.23 \mathrm{eV}$, respectively. It was indeed seen that $\mathrm{Al}_{24} \mathrm{Sc}_{6} \mathrm{Zr}_{2}$ was slightly wider than the pseudogap of $\mathrm{Al}_{3} \mathrm{Sc}$, while that of $\mathrm{Al}_{24} \mathrm{Sc}_{6} \mathrm{M}_{2}(\mathrm{M}=\mathrm{Ti} / \mathrm{Y} / \mathrm{Li})$ was slightly narrower. This proved that $\mathrm{Al}_{24} \mathrm{Sc}_{6} \mathrm{Zr}_{2}$ had a stronger covalent bond, which was the most stable $[13,14,23]$. However, the stability of $\mathrm{M}(\mathrm{M}=\mathrm{Ti} / \mathrm{Y} / \mathrm{Li})$ doped $\mathrm{Al}_{3} \mathrm{Sc}$ was weakened. This was consistent with the calculation of the formation energy in Table 1.

The reason for this consequence, the $\mathrm{Zr}-d$ orbital provided more valence electrons to hybridize with the Al- $p$ orbital than the Sc- $d$ orbital, while the Ti- $d$ orbital provided fewer valence electrons. At the same time, there was a stronger $d-d$ bond interaction between the Sc and $\mathrm{Zr}$ atoms, which effectively enhanced the ductility of the material [45]. For the $\mathrm{Al}_{24} \mathrm{Sc}_{6} \mathrm{Li}_{2}$ structure, the $\mathrm{Li}$ atom replaced the $\mathrm{Sc}$ atom, and reduced the $p-d$ hybridization. The number of bonding electrons per atom in $\mathrm{Al}_{3} \mathrm{Sc}$ and Al-Sc-M ( $\mathrm{M}=\mathrm{Zr}$, Ti, $\mathrm{Y}$, and $\mathrm{Li})$ structures in the low energy region are shown in Figure 7, which were $2.94,3.022,2.994,2.943$, and 2.811, accordingly (energy range between-12 eV and Fermi levels). It is well-known that a higher number of bonding electrons implies an increased structural stability [34,46]. Thus, a stronger electron interaction should occur in $\mathrm{Al}_{24} \mathrm{Sc}_{6} \mathrm{Zr}_{2}$, and $\mathrm{Al}_{24} \mathrm{Sc}_{6} \mathrm{Zr}_{2}$ should have a larger 
structural stability. It was considered that as $\mathrm{Zr}$ had more valence electrons, it resulted in stronger electron interactions between the $\mathrm{Zr}-d$ orbital and the Al- $p$ orbital, as well as between $(\mathrm{Sc}, \mathrm{Zr})-d$ [45,47].
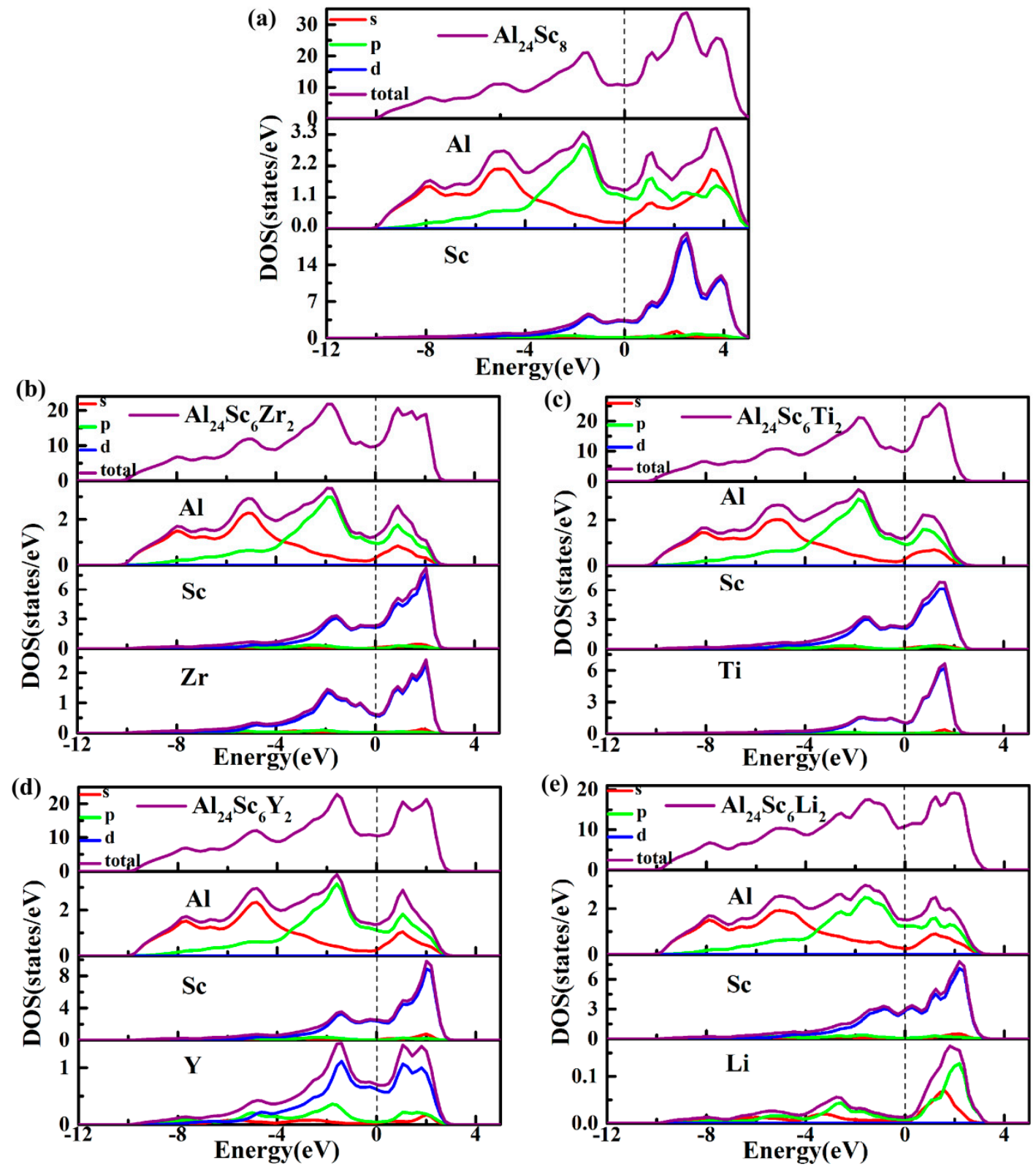

Figure 7. Total density of states (TDOSs) and Partial density of states (PDOSs) of (a) $\mathrm{Al}_{3} \mathrm{Sc}$ and (b-e) $\mathrm{Al}_{24} \mathrm{Sc}_{6} \mathrm{M}_{2}(\mathrm{M}=\mathrm{Zr}, \mathrm{Ti}, \mathrm{Y}$, and Li) alloys. TDOSs for different structures and different elements are represented by purple lines. PDOSs for different orbitals are denoted by $s$ in red, $p$ in green and $d$ in blue.

To further illustrate the contribution of each atomic orbital to TDOS, the PDOS of each atom were calculated, as shown in Figure 7. The main bonding peaks of $\mathrm{Al}_{24} \mathrm{Sc}_{6} \mathrm{M}_{2}$ were predominantly derived from the Al-s and Al- $p$ orbitals, in the energy range between $-12 \mathrm{eV}$ and $-4 \mathrm{eV}$ (Figure $7 \mathrm{~b}-\mathrm{e}$ ), making the TDOS of $\mathrm{Al}_{24} \mathrm{Sc}_{6} \mathrm{M}_{2}$ almost coincident with the $\mathrm{Al}_{3} \mathrm{Sc}$.

It could be clearly observed that, from $-4 \mathrm{eV}$ to $5 \mathrm{eV}$, the TDOS was mainly contributed by the strong hybridization of the $\mathrm{Al}(\mathrm{Li})-p$ and $\mathrm{Sc}(\mathrm{Zr} / \mathrm{Ti} / \mathrm{Y})-d$ orbitals, and a small contribution of $\mathrm{Al}-s$ was also observed. Additionally, there was a large overlap in the entire energy range, leading to a strong $p d$ hybridization. The pseudogap was generated by the hybridization of Al- $p$ and $\mathrm{M}-d(\mathrm{M}=\mathrm{Sc}, \mathrm{Zr}, \mathrm{Ti}, \mathrm{Y})$. 
In other words, there was a strong covalent bond in the Al-Sc-M (M $=\mathrm{Zr}, \mathrm{Ti}, \mathrm{Y}$, and Li) structure. In addition, the PDOS of $\mathrm{Zr} / \mathrm{Ti} / \mathrm{Y}-d$ orbitals were different from the Sc- $d$ orbital, suggesting that the doping elements should have taken effect on the TDOS. Below the Fermi level, the peaks of $\mathrm{Zr}-d$ orbital moved toward to the lower energy level (Figure $7 \mathrm{~b}$ ), contributing to the enhancement of the bonding states of $\mathrm{Al}_{24} \mathrm{Sc}_{6} \mathrm{Zr}_{2}$. Regardless, the Sc- $d$ orbital of $\mathrm{Al}_{24} \mathrm{Sc}_{6} \mathrm{Li}_{2}$ moved toward the higher level (Figure 7e). Moreover, the magnitudes of Li-s/p orbitals were tiny, compared to the other atomic orbitals. This implied that there was a weaker covalent bond in $\mathrm{Al}_{24} \mathrm{Sc}_{6} \mathrm{Li}_{2}$ for the subdued hybridization between $\mathrm{Li}$ and Sc atoms.

For a deeper insight into the atomic bonding of the doped structures, the valence electron density distribution were also investigated. For example, the charge densities on the (100) and (110) planes, for each cell, are shown in Figure 8, in which the contour lines are plotted from 0.015 to $0.04 \mathrm{e} / \AA^{3}$ with $0.0025 \mathrm{e} / \AA^{3}$ interval.
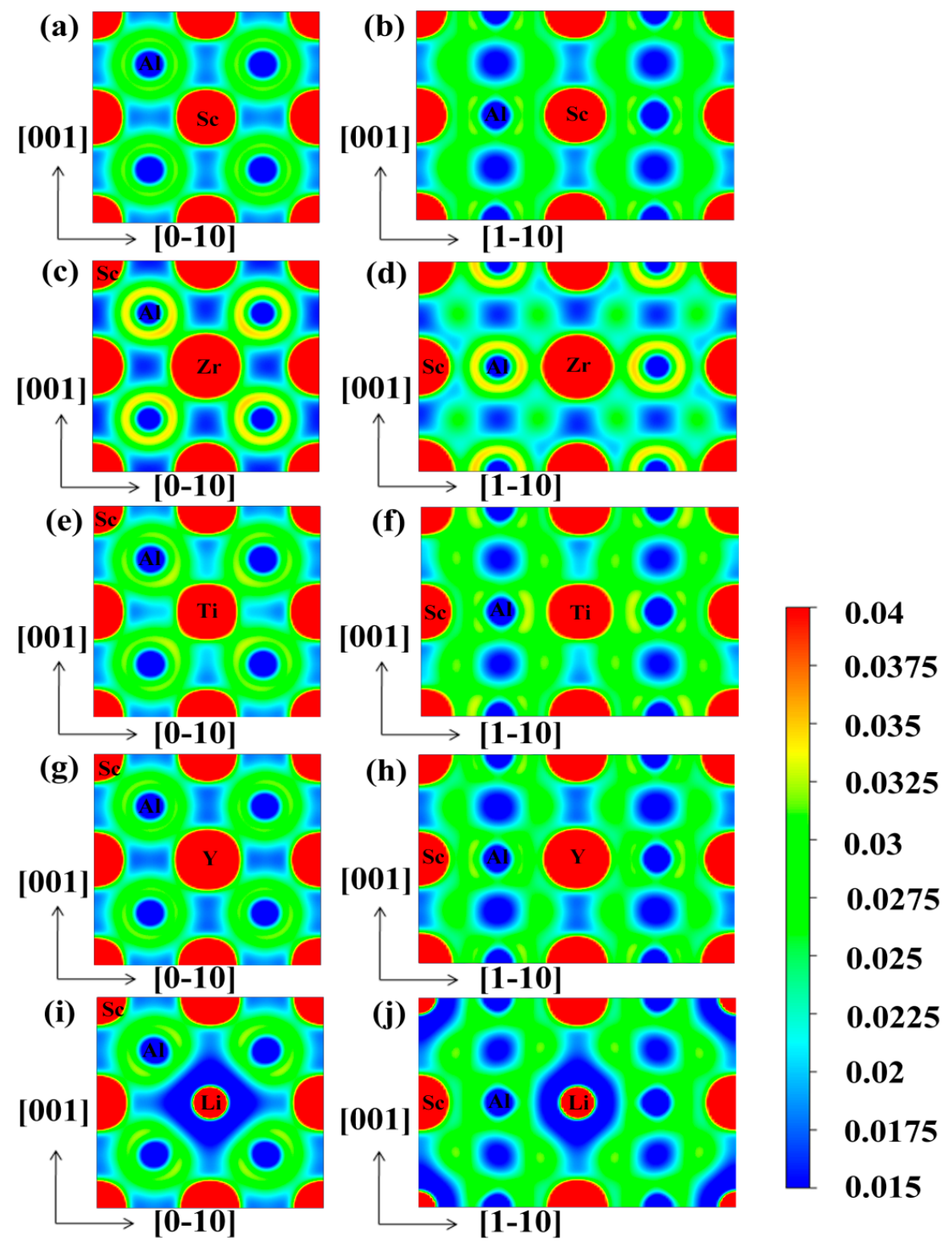

0.0225

0.02

0.0175

0.015

Figure 8. The electron density contour plots (Unit: e/ $\AA^{3}$ ) on the (100) and (110) planes for $\mathrm{L}_{2}-\mathrm{Al}_{3} \mathrm{Sc}$ $(\mathbf{a}, \mathbf{b}), \mathrm{L}_{2}-\mathrm{Al}_{24} \mathrm{Sc}_{6} \mathrm{Zr}_{2}(\mathbf{c}, \mathbf{d}), \mathrm{L}_{2}-\mathrm{Al}_{24} \mathrm{Sc}_{6} \mathrm{Ti}_{2}(\mathbf{e}, \mathbf{f}), \mathrm{L1}_{2}-\mathrm{Al}_{24} \mathrm{Sc}_{6} \mathrm{Y}_{2}(\mathbf{g}, \mathbf{h})$, and $\mathrm{L}_{2}-\mathrm{Al}_{24} \mathrm{Sc}_{6} \mathrm{Li}_{2}(\mathbf{i}, \mathbf{j})$.

Figure $8 \mathrm{a}, \mathrm{b}$ display the charge distribution of pure $\mathrm{Al}_{3} \mathrm{Sc}$ on the (100) and (110) planes, respectively. It was clearly observed that the charge densities of the neighboring Al-Al, Al-Sc, and Sc-Sc had overlaps, 
especially between the $\mathrm{Al}-\mathrm{Sc}$, indicating that there were strong covalent bonds in $\mathrm{Al}_{3} \mathrm{Sc}$. Moreover, these covalent bonds were mainly generated by the hybridization between Al- $p$ and Sc- $d$ orbitals. Compared with (110) plane, the charge distribution between the neighboring Al-Sc on the (100) surface was weak, which proved that the covalent bond on the (110) plane was stronger, leading to a brittle fracture. This was caused by the difference in the local symmetries between the (100) and (110) plane. This feature was consistent with previous reports [36]. The charge densities of $\mathrm{Al}_{24} \mathrm{Sc}_{6} \mathrm{Zr}_{2}$ (100) and the (110) planes are shown in Figure $8 c, d$, respectively. The overlap of the charge density between the neighboring $\mathrm{Al}-\mathrm{Zr}$ was increased, which meant that the covalent bond was enhanced. Moreover, $\mathrm{Zr}$ was slightly less electronegative than Sc. On this account, $\mathrm{Al}-\mathrm{Zr}$ exhibited weaker ionic bond properties. This property could be analyzed by the Bader charge $[48,49]$. The calculation results showed that 0.38 electrons were transferred from $\mathrm{Sc}$ to $\mathrm{Al}$ in $\mathrm{Al}_{3} \mathrm{Sc}$. Nevertheless, the charge transferred from ( $\mathrm{Sc}, \mathrm{Zr}$ ) to $\mathrm{Al}$ was reduced to 0.34 , and the charge distribution on the $\mathrm{Sc}$ atom remained unchanged. However, the bonding difference between (100) and (110) planes was decreased, which was profitable for the improvement of the ductility of $\mathrm{Al}_{24} \mathrm{Sc}_{6} \mathrm{Zr}_{2}$ [24]. The charge distributions of the $\mathrm{Al}_{3} \mathrm{Sc}$ doped with $\mathrm{Ti}$ and $\mathrm{Y}$ are shown in Figure 8e-h, accordingly. In contrast to the $\mathrm{Al}_{24} \mathrm{Sc}_{6} \mathrm{Zr}_{2}$, the overlaps of charge density between $\mathrm{Al}-\mathrm{Ti} / \mathrm{Y}, \mathrm{Sc}-\mathrm{Ti}$, and $\mathrm{Sc}-\mathrm{Sc}$ were reduced, implying that the covalent bonds were weakened. The charge density distributions of $\mathrm{Al}_{3} \mathrm{Sc}$ doped with $\mathrm{Li}$ are shown in Figure 8i,j. It was observed that the charge density overlap between Sc-Li decreased, indicating that Sc-Li exhibited a weaker covalent bond, which was mainly contributed by the hybridization of the Sc- $d$ and Li- $p$ states.

\section{Conclusions}

In order to explore the effects of the doped elements $(\mathrm{M})$ on the mechanical properties of $\mathrm{Al}_{3} \mathrm{Sc}$, both, the structural stability and mechanical properties of $\mathrm{Al}_{3} \mathrm{Sc}$ with different doping elements and concentrations, in combination with the influence of the higher doping concentration on the electronic properties of $\mathrm{Al}_{3} \mathrm{Sc}$ were systematically investigated using the first-principles methods. Based on the results of this study, the following conclusions could be deduced. First, it was observed that the $\mathrm{Al}_{3} \mathrm{Sc}$ structure could be stable after doping. For instance, $\mathrm{Al}-\mathrm{Sc}-\mathrm{Zr}$ had the highest stability, and $\mathrm{Al}_{24} \mathrm{Sc}_{6} \mathrm{Zr}_{2}$ performed better on stability, compared to $\mathrm{Al}_{24} \mathrm{Sc}_{7} \mathrm{Zr}$. On the other hand, $\mathrm{Al}-\mathrm{Sc}-\mathrm{M}(\mathrm{M}=\mathrm{Ti}, \mathrm{Y}, \mathrm{Li})$ reduced the stability of $\mathrm{Al}_{3} \mathrm{Sc}$, and $\mathrm{Al}_{24} \mathrm{Sc}_{6} \mathrm{M}_{2}$ performed worse on stability, compared with $\mathrm{Al}_{24} \mathrm{Sc}_{7} \mathrm{M}$. The calculated elastic constants of $\mathrm{Al}_{3} \mathrm{Sc}$, before and after doping, showed its mechanical stability. Moreover, the calculated $B / G$ results revealed that the doped $\mathrm{Al}_{3} \mathrm{Sc}$ with a higher concentration exhibited a better ductility, especially, when doped with $\mathrm{Zr}$ and Ti. It was noted that, the calculated results of the elastic modulus $B, G, E$, and $v$ suggested that both $\mathrm{Al}_{24} \mathrm{Sc}_{6} \mathrm{Zr}_{2}$ and $\mathrm{Al}_{24} \mathrm{Sc}_{6} \mathrm{Ti}_{2}$ displayed better mechanical properties. Additionally, the TDOS and PDOS analyses indicated that the doped $\mathrm{Al}_{3} \mathrm{Sc}$ had a pseudogap and a strong covalent bonding, which was due to the strong $p d$ state hybridization. Among them, the maximum pseudogap existed in $\mathrm{Al}_{24} \mathrm{Sc}_{6} \mathrm{Zr}_{2}$, indicating its best stability. This conclusion was consistent with the calculated formation enthalpy. Ultimately, the obtained results could provide an important theoretical basis for a wide application of the Al-Sc alloy.

Author Contributions: Conceptualization, D.C., X.L. and M.W.; Methodology, X.L. and M.W.; Software, X.L. and M.W.; Formal Analysis, D.C., C.X., Y.W., X.L. and M.W.; Investigation, D.C. and X.L.; Data Curation, D.C., X.L. and M.W.; Writing-Original Draft Preparation, D.C.; Writing-Review \& Editing, C.X., Y.W., X.L. and M.W.; Funding Acquisition, Y.W.

Funding: This work was sponsored by the National Key Research and Development Program of China (Grant No.2018YFB1106302), and the project (Grant No. 2017WAMC002), sponsored by the Anhui Province Engineering Research Center of Aluminum Matrix Composites (China).

Conflicts of Interest: The authors declare no conflict of interest.

\section{References}

1. Asta, M.; Ozolinš, V. Structural, vibrational, and thermodynamic properties of Al-Sc alloys and intermetallic compounds. Phys. B 2001, 64, 094104. [CrossRef] 
2. Asta, M.; Ozolins, V.; Woodward, C. A first-principles approach to modeling alloy phase equilibria. JOM 2001, 53, 16-19. [CrossRef]

3. Marquis, E.A.; Seidman, D.N. Nanoscale structural evolution of $\mathrm{Al}_{3} \mathrm{Sc}$ precipitates in $\mathrm{Al}(\mathrm{Sc})$ alloys. Acta Mater. 2001, 49, 1909-1919. [CrossRef]

4. Ebrahimi, Z.; Ebrahimi, H. Effects of elastic contributions on the evolution of nano-structure $\mathrm{Al}_{3} \mathrm{Sc}$ phase: A phase-field study. Sci. Iran. 2016, 23, 1539-1548. [CrossRef]

5. Raghukiran, N.; Sujith, R.; Agrawal, H.; Shabadi, R.; Kumar, R. In situ age hardening and grain refinement in as-sprayed Al-Sc binary alloy deposits. J. Alloys Compd. 2018, 735, 1596-1602. [CrossRef]

6. Kundu, S.; Thirunavukarasu, G.; Chatterjee, S.; Mishra, B. Effect of Bonding Temperature on Phase Transformation of Diffusion-Bonded Joints of Duplex Stainless Steel and Ti-6Al-4V Using Nickel and Copper as Composite Intermediate Metals. Met. Mater. Trans. A 2015, 46, 5756-5771. [CrossRef]

7. Jiang, C.; Sordelet, D.; Gleeson, B. Effects of Pt on the elastic properties of B2 NiAl: A combined first-principles and experimental study. Acta Mater. 2006, 54, 2361-2369. [CrossRef]

8. Jia, M.; Zheng, Z.; Gong, Z. Microstructure evolution of the 1469 Al-Cu-Li-Sc alloy during homogenization. J. Alloys Compd. 2014, 614, 131-139. [CrossRef]

9. Lai, J.; Zhang, Z.; Chen, X.-G. Precipitation strengthening of Al-B $\mathrm{B}_{4} \mathrm{C}$ metal matrix composites alloyed with Sc and Zr. J. Alloy. Compd. 2013, 552, 227-235. [CrossRef]

10. Mo, Y.; Pang, M.; Yang, W.; Zhan, Y. Effects of alloying elements on structural, electronic and mechanical properties of AlSc2 by first-principles calculations. Comput. Mater. Sci. 2013, 69, 160-167. [CrossRef]

11. Park, N.; Lee, S.-C.; Cha, P.-R. Effects of alloying elements on the stability and mechanical properties of Fe3Al from first-principles calculations. Comput. Mater. Sci. 2018, 146, 303-309. [CrossRef]

12. Tian, J.; Zhao, Y.; Hou, H.; Wang, B. The effect of alloying elements on the structural stability, mechanical properties, and Debye temperature of $\mathrm{Al}_{3} \mathrm{Li}$ : A first-principles study. Materials 2018, 11, 1471. [CrossRef] [PubMed]

13. Fuller, C.B.; Seidman, D.N.; Dunand, D.C. Mechanical properties of Al(Sc,Zr) alloys at ambient and elevated temperatures. Acta Mater. 2003, 51, 4803-4814. [CrossRef]

14. Van Dalen, M.E.; Dunand, D.C.; Seidman, D.N. Effects of Ti additions on the nanostructure and creep properties of precipitation-strengthened Al-Sc alloys. Acta Mater. 2005, 53, 4225-4235. [CrossRef]

15. Mao, Z.; Chen, W.; Seidman, D.; Wolverton, C. First-principles study of the nucleation and stability of ordered precipitates in ternary Al-Sc-Li alloys. Acta Mater. 2011, 59, 3012-3023. [CrossRef]

16. Harada, Y.; Dunand, D.; Dunand, D. Thermal expansion of Al3Sc and Al3(Sc0.75X0.25). Scr. Mater. 2003, 48, 219-222. [CrossRef]

17. Harada, Y.; Dunand, D.; Dunand, D. Creep properties of $\mathrm{Al}_{3} \mathrm{Sc}$ and $\mathrm{Al}_{3}(\mathrm{Sc}, \mathrm{X})$ intermetallics. Acta Mater. 2000, 48, 3477-3487. [CrossRef]

18. Li, D.L.; Chen, P.; Yi, J.X.; Tang, B.Y.; Peng, L.M.; Ding, W.J. Ab initio study on the thermal properties of the fcc Al3Mg and Al3Sc alloys. J. Phys. D Appl. Phys. 2009, 42, 225407. [CrossRef]

19. Hu, W.-C.; Liu, Y.; Li, D.-J.; Zeng, X.-Q.; Xu, C.-S. Mechanical and thermodynamic properties of Al3Sc and $\mathrm{Al} 3 \mathrm{Li}$ precipitates in Al-Li-Sc alloys from first-principles calculations. Phys. B Condens. Matter. 2013, 427, 85-90. [CrossRef]

20. Chen, D.; Chen, Z.; Wu, Y.; Wang, M.; Ma, N.; Wang, H. First-principles investigation of mechanical, electronic and optical properties of $\mathrm{Al}_{3} \mathrm{Sc}$ intermetallic compound under pressure. Comput. Mater. Sci. 2014, 91, 165-172. [CrossRef]

21. Pan, R.-K.; Wang, H.-C.; Shao, L.; Zheng, J.; Pan, X.-Z.; Tang, B.-Y. Temperature dependence of elastic properties of $\mathrm{L} 1_{2}-\mathrm{Al}_{3} \mathrm{Sc}$ : A first-principles study. Comput. Mater. Sci. 2016, 111, 424-429. [CrossRef]

22. Duan, Y.H.; Sun, Y.; Peng, M.J.; Zhou, S.G. Ab-initio investigations on elastic properties in $\mathrm{L}_{2}$ structure $\mathrm{Al}_{3} \mathrm{Sc}$ and $\mathrm{Al}_{3} \mathrm{Y}$ under high pressure. J. Alloys Compd. 2014, 585, 587-593. [CrossRef]

23. Wang, R.N.; Ma, L.; Pan, R.K.; Luo, T.P.; Zhou, S.C.; Tang, B.Y. First-principles study of $\mathrm{L1}_{2}-\mathrm{Al}_{3}\left(\mathrm{Sc}_{1-\mathrm{x}} \mathrm{TM}_{\mathrm{x}}\right)$ alloys using special quasirandom structures. Comput. Mater. Sci. 2013, 79, 136-142. [CrossRef]

24. Huang, Y.C.; Guo, X.F.; Ma, Y.L.; Shao, H.B.; Xiao, Z.B. Stabilities, electronic and elastic properties of $\mathrm{L}_{2}-\mathrm{Al}_{3}\left(\mathrm{Sc}_{1-x}, \mathrm{Zr}_{\mathrm{x}}\right)$ with different $\mathrm{Zr}$ content: A first-principles study. Phys. B Condens. Matter 2018, 548, 27-33. [CrossRef]

25. Khenioui, Y.; Boulechfar, R.; Maazi, N.; Ghemid, S. FP-LAPW investigation of $\mathrm{Al}_{3}\left(\mathrm{Sc}_{1-\mathrm{x}} \mathrm{Ti}_{\mathrm{x}}\right)$ alloys properties in $\mathrm{L}_{2}$ and $\mathrm{D0}_{22}$ structures. Int. J. Mod. Phys. B 2018, 32, 1850167. [CrossRef] 
26. Kresse, G.; Furthmüller, J. Efficient iterative schemes for ab initio total-energy calculations using a plane-wave basis set. Phys. Rev. B 1996, 54, 11169-11186. [CrossRef]

27. Kresse, G.; Joubert, D. From ultrasoft pseudopotentials to the projector augmented-wave method. Phys. Rev. B 1999, 59, 1758-1775. [CrossRef]

28. Perdew, J.P.; Burke, K.; Ernzerhof, M. Generalized Gradient Approximation Made Simple. Phys. Lett. 1996, 77, 3865-3868. [CrossRef]

29. Monkhorst, H.J.; Pack, J.D. Special points for Brillouin-zone integrations. Phys. Rev. B 1976, 13, 5188-5192. [CrossRef]

30. Qian, Y.; Xue, J.L.; Wang, Z.J.; Yang, Z.H.; Qian, P. Mechanical properties evaluation of Zr addition in $\mathrm{L}_{2}-\mathrm{Al}_{3}\left(\mathrm{Sc}_{1-\mathrm{x}} \mathrm{Zr}_{\mathrm{x}}\right)$ using first-principles calculation. JOM 2016, 68, 1293-1300. [CrossRef]

31. Tian, T.; Wang, X.F.; $\mathrm{Li}, \mathrm{W}$. $\mathrm{Ab}$ initio calculations on elastic properties in $\mathrm{L1}_{2}$ structure $\mathrm{Al}_{3} \mathrm{X}$ and $\mathrm{X}_{3} \mathrm{Al}$-type $(\mathrm{X}=$ transition or main group metal) intermetallic compounds. Solid State Commun. 2013, 156, 69-75. [CrossRef]

32. Shi, D.; Wen, B.; Melnik, R.; Yao, S.; Li, T. First-principles studies of Al-Ni intermetallic compounds. J. Solid State Chem. 2009, 182, 2664-2669. [CrossRef]

33. Hill, R. The Elastic Behaviour of a Crystalline Aggregate. Proc. Phys. Soc. Sect. A 1952, 65, 349-354. [CrossRef]

34. Zhou, L.J.; Su, K.H.; Wang, Y.L.; Zeng, Q.F.; Li, Y.L. First-principles study of the properties of Li, $\mathrm{Al}$ and Cd doped Mg alloys. J. Alloys Compd. 2014, 596, 63-68. [CrossRef]

35. Young, A.F.; Sanloup, C.; Gregoryanz, E.; Scandolo, S.; Hemley, R.J.; Mao, H.-K. Synthesis of Novel Transition Metal NitridesIrN $\mathrm{N}_{2}$ andOsN $\mathrm{N}_{2}$. Phys. Lett. 2006, 96, 155501. [CrossRef] [PubMed]

36. Wang, R.N.; Tang, B.Y.; Peng, L.M.; Ding, W.J. Ab initio study of the effect of Zr content on elastic and electronic properties of $\mathrm{L} 1_{2}-\mathrm{Al} 3\left(\mathrm{Sc}_{1-x} \mathrm{Zr}_{\mathrm{x}}\right)$ alloys. Comput. Mater. Sci. 2012, 59, 87-93. [CrossRef]

37. Teter, D.M. Computational Alchemy: The Search for New Superhard Materials. MRS Bull. 1998, $23,22-27$. [CrossRef]

38. Pugh, S. XCII. Relations between the elastic moduli and the plastic properties of polycrystalline pure metals. Lond. Edinb. Dublin Philos. Mag. J. Sci. 1954, 45, 823-843. [CrossRef]

39. Pettifor, D.G. Theoretical predictions of structure and related properties of intermetallics. Mater. Sci. Technol. 1992, 8, 345-349. [CrossRef]

40. Mattesini, M.; Ahuja, R.; Johansson, B. Cubic $\mathrm{Hf}_{3} \mathrm{~N}_{4}$ and $\mathrm{Zr}_{3} \mathrm{~N}_{4}$ : A class of hard materials. Phys. B 2003, $68,184108$.

41. Tvergaard, V.; Hutchinson, J.W. Microcracking in Ceramics Induced by Thermal Expansion or Elastic Anisotropy. J. Am. Ceram. Soc. 1988, 71, 157-166. [CrossRef]

42. Anderson, O.L. A simplified method for calculating the debye temperature from elastic constants. J. Phys. Chem. Solids 1963, 24, 909-917. [CrossRef]

43. Ravindran, P.; Fast, L.; Korzhavyi, P.A.; Johansson, B.; Wills, J.; Eriksson, O. Density functional theory for calculation of elastic properties of orthorhombic crystals: Application to TiSi 2 . J. Appl. Phys. 1998, 84, 4891-4904. [CrossRef]

44. Sun, Z.M.; Ahuja, R.; Schneider, J.M. Theoretical investigation of the solubility in $\left(\mathrm{M}_{\mathrm{x}} \mathrm{M}_{2-\mathrm{x}}^{\prime}\right) \mathrm{AlC}\left(\mathrm{M}\right.$ and $\mathrm{M}^{\prime}=$ Ti, V, Cr). Phys. Rev. B 2003, 68, 224112. [CrossRef]

45. Tian, J.; Han, G.; Wei, H.; Zheng, Q.; Jin, T.; Sun, X.; Hu, Z. Effects of alloying elements on the electronic structure and ductility of NiAl compounds investigated by X-ray absorption fine structure. Philos. Mag. 2013, 93, 2161-2171. [CrossRef]

46. Nylén, J.; Garcìa, F.G.; Mosel, B.; Pöttgen, R.; Häussermann, U. Structural relationships, phase stability and bonding of compounds PdSn $(n=2,3,4)$. Solid State Sci. 2004, 6, 147-155. [CrossRef]

47. Electronic structure and hybridization effects in Hume-Rothery alloys containing transition elements. Phys. Rev. B 1995, 52, 7920-7933. [CrossRef]

48. Bader, R. Atoms in Moledules: A Quantum Theory; Oxford University Press: New York, NY, USA, 1990.

49. Delaire, O.; Fultz, B. Charge redistribution and rhonon entropy of Vanadium alloys. Phys. Rev. Lett. 2006, 97, 245701. [CrossRef]

(C) 2019 by the authors. Licensee MDPI, Basel, Switzerland. This article is an open access article distributed under the terms and conditions of the Creative Commons Attribution (CC BY) license (http://creativecommons.org/licenses/by/4.0/). 